\title{
The Implementation of the 3R Principle on the Household Solid Waste Management in Sleman, Yogyakarta
}

\author{
Ridayati $^{1, *}$ A.Yunastiawan ${ }^{2}$ \\ ${ }^{1}$ Civil Engineering Department, Institut Teknologi Nasional Yogyakarta, Indonesia \\ ${ }^{2}$ Urban and Regional Planning Department, Institut Teknologi Nasional Yogyakarta, Indonesia \\ *Corresponding author.Email: ridayati@itny.ac.id
}

\begin{abstract}
The urbanization process has caused several problems, such as clean water, environmental degradation, and waste management, especially in the peri-urban area. The solid waste management system is a type of basic urban infrastructure that often faces the problem of overcapacity in the peri-urban area. To deal with this problem, the concept of reducing and recycling household waste becomes an alternative to reduce the burdens to the municipal solid waste management system. The concept of reducing and recycling waste is well known as the $3 \mathrm{R}$ principle (3R) which consists of reduce, reuse, and recycle waste.

This research is intended to measure the level of knowledge, attitude, and practice of the household towards the 3R Principle in the peri urban area in Sleman, Yogyakarta. As the part of Yogyakarta Conurbation Area, the peri-urban area in Sleman often faces the problem of household solid waste management. This research compares the level of knowledge, attitude, and practice of the household in urban and peri-urban areas. A set of questionaire was used as the data collection instrument to measure the knowledge attitude and practice towards the application of the 3R principle among households in the Mlati District as part of the Yogyakarta Conurbation Area.

This research shows that despite a high level of knowledge and attitude towards the 3R Principle, it was not in line with the practice of this principle in household solid waste management. The lack of awareness regarding citizen participation in the household waste management system and the problem in the household waste collection is seen as the most important factor that makes the $3 \mathrm{R}$ principle could not be well-applied in the case study area.
\end{abstract}

Keywords: household, solid waste, $3 R$.

\section{INTRODUCTION}

Urban area in the world is experiencing dramatic grow recently [1]. The urban physical growth also becomes the generator of economic activities. On the other hand, the urbanization process has caused several problems, such as clean water, environmental degradation, and also waste management. The periurban is not well-prepared to contain urbanization. As a consequence, the urban infrastructure faces the problem of over-capacity $[1,2]$.

Rapid urban growth, which lead to increase in welfare, has also increase the amount of solid waste produced by households [3]. In the developing countries, problems that may occur consists of lack of individual awareness on the solid waste management and the poor strategies on waste collection ([4], and the imperfection or lack of the local government capacity to manage solid waste $[5,6]$.
Acknowledging that the number of household solid waste could be a big problem, the concept of reducing and recycling household waste becomes an alternative to reduce the burdens to the municipal solid waste management system [7]. The concept of reducing and recycling waste is well known as the $3 \mathrm{R}$ Principle or reduce, reuse and recycle of waste. The application of the $3 \mathrm{R}$ principle is started at the household level, which to segregates their solid waste [8].

In order to apply the $3 \mathrm{R}$ principle successfully, it is important to ensure the household participation in the municipal solid waste management. In the previous research, the household engagement on the municipal solid waste management was measure through their knowledge, attitude, and practice towards the municipal solid waste management [2,6]. The household has a good knowledge and attitude towards the participation on the municipal solid waste 
management [2, 3, 5]. However, most of the households do not have the high score on the practice aspect, which imply that their knowledge and attitude towards the participation on the municipal solid waste management is not followed by the implementation on it.

The gap between knowledge, attitude, and practice towards the household participation on the municipal solid waste management has been indicated in previous research, which are conducted in several context. It is also important to learn the similar case in other context, especially in the middle income country, to build a body of knowledge regarding the application of the $3 R$ Principle in the municipal solid waste management system.

This urban growth also occurs at the major and middle cities in Indonesia. The urbanization is marked by the physical growth of the urban core to its periphery. This phenomenon is well-known as the periurbanization $[9,10]$. Yogyakarta is one of middle-size city in Indonesia that faces the physical growth during the last decade [8,9]. This physical growth has caused change on its surrounding area, which one of them is Sleman Regency [13]. Sleman Regency, located on the North of Yogyakarta, initially had the rural characteristics. Its characteristics had been changed into urban due to the urbanization process [14].. The urbanization process in Yogyakarta has formed a conurbation area, namely Yogyakarta Urban Area (Kawasan Perkotaan Yogyakarta/KPY) [15]. Similar with other urban areas in Indonesia, the Yogyakarta Urban Area also faces the problem of basic infrastructure provision.

One of $\mathrm{t}$ problem in the basic infrastructure provision in Yogyakarta is regarding the waste management. Waste management system is vital for the urban society, especially for the hygiene and the aesthetics [16]. The main problem is regarding the landfill capacity. The landfill, which is located on Piyungan, Bantul Regency, often stops its operation due to the over-capacity problem [17, 18]. This operational problems has caused many effects, especially the waste-pile in the urban main street in the Yogyakarta Urban Area.

The problem of the landfill capacity needs an urgent solution to avoid the problem of over-capacity in the future. One of the possible solution is to reduce the household waste volume to be dumped in the landfill. The application of the 3R Principle in the waste management could be a possible solution to reduce the waste to be dumped to the landfill [19]. However, this principle needs a strong commitment and supports from the citizen, and also good waste management system [20].

A study is then conducted to investigate the preparedness of the local people to apply the 3R principle. This study was conducted in Mlati SubDistrict, which is located in the peri-urban area and currently is facing a high urbanization rate. Half of the district is densely populated, thus the waste management system becomes a problem that needs to be solved urgently. This study would like to contribute in the local policy regarding waste management system, hence also gives a theoretical contribution regarding the application of the $3 \mathrm{R}$ principle.

\section{METHODS}

This research is intended to measure the level of knowledge, attitude, and practice of the household in the peri urban area in the middle size city in Indonesia. The peri urban area is facing a rapid growth, which separate this area into two main areas, which are urbanized area and the less urbanized area. Since the urbanization process is still occuring, the less urbanized area will be more urbanized in the future, which also may lead to the solid waste management problems in the future. To anticipate the effect of the rapid urbanization, this research is conducted. The area selected as the case study location is the Mlati District, which is located in Yogyakarta Urban Area. This area is facing a rapid urbanization trends during the last 10 years. The urbanization process has separated the district into two main areas, which are the urbanized area and the less urbanized area. This research compares the level of knowledge, attitude, and practice of the household who reside in the urbanized area and the household who reside in the less urbanized area.

A set of questionnaire was introduced for the purpose of this study. This questionnaire consists of 40 questions regarding the knowledge, attitude, and practice towards the application of the 3R Principle among households in the Mlati District. The questionnaire itself has been tested using reliability test (Cronbach-Alpha) in IBM SPSS 20. There are 300 respondents from different households that were randomly selected as the survey respondents. All of the respondents reside in Sendangadi and Sinduadi SubDistrict, which are delineated as the part of Yogyakarta Urban Area/KPY based on the Sleman Regency Spatial Plan Document (Rencana Tata Ruang Wilayah Kabupaten Sleman) 2011-2031. The sample number was determined using quota random sampling, with 150 respondents represent each sub-districts in the study area. The data was then analyzed to figure out the proportion of the respondents based on the knowledge, 
attitude, and practice towards the application of $3 \mathrm{R}$ Principle in the household waste management.

\section{RESULT AND DISCUSSION}

\subsection{Solid Waste Management System in Sleman Regency}

Mlati District is one of the sub-districts that is administratively located in the Sleman Regency. Part of Mlati Subdistrict, namely Sinduadi Village and Sendangadi Village in the RTRW document for Sleman Regency 2011-2031 is determined to be part of the Yogyakarta Urban Area, which means that the two villages are part of the Sleman Regency area designated as the National Activity Center (PKN).

Household waste management in Mlati District is generally divided into at least 3 (three) categories, namely waste that is managed independently by each household, waste managed by the Independent Waste Management Institute formed by the community, and waste managed by officers. from the Sleman Regency Government. Based on the data obtained, it is known that the coverage of solid waste services by the government in Sleman Regency has only reached 25$50 \%$ in the Mlati District area. Meanwhile, other household waste is generally managed by independent waste management groups. Household waste in solid form after being managed either by government officials or by independent waste management agencies is then transported to the only Integrated Waste Disposal Site (TPST) in the Yogyakarta Special Region, namely TPST Piyungan.

In Mlati District, there were initially two transfer depots, namely in Kragilan and in Pogung Kidul. However, currently available is transfer depot in Kragilan, Sinduadi. Meanwhile, the transfer depot in Pogung Kidul is currently closed and no longer functional because the land to the north of the former depot transfer is currently being used to develop the Taman Melati apartment.

In the area of Mlati District, there are several trash containers. In the village area of Sinduadi, there are two containers placed in the area of Dr.Sarjito Hospital and PT Kharisma Prima Abadi.

Waste management in the Sleman Regency area generally ends in spearheading the 3R TPS managers who are in each hamlet or Rukun Tetangga. TPS $3 \mathrm{R}$ is managed by a non-governmental organization formed by residents at the hamlet or Rukun Tetangga level. In this TPS $3 R$, the waste is sorted, with some organic waste material being processed into compost, and materials that cannot be managed at the TPS 3R level can be disposed of or transported to the depot transfer.

\subsection{Practice of the Household Waste Management}

Based on the results of data collection through questionnaires, it can be seen that most respondents still manage their waste independently. As many as $48 \%$ of the total respondents stated that they manage their household waste independently. As many as $26 \%$ of respondents stated that their household waste was transported by officers. Meanwhile, the remaining $26 \%$ of the total respondents stated that part of their household waste was managed by themselves and partly transported by officers. This condition indicates that most of the volume of household waste generated by respondents is still managed independently.

The management of household waste which is still managed independently can cause problems, considering that most of the waste is managed by burning. Garbage that is burned, either independently or in groups, can cause air pollution problems. As many as $68 \%$ of respondents who manage their waste independently stated that the household waste produced is managed by burning it. The rest, $29 \%$ of the total number of respondents stated that their waste was managed by hoarding, and only $3 \%$ of the total number of respondents who recycled the generated household waste.

From the respondents' answers, it is known that the garbage in their environment is not taken by officers every day. Most of the respondents, namely $39 \%$ of the total respondents, stated that their household waste was only collected once a week by officers. Meanwhile, $31 \%$ of the total number of respondents stated that their household waste was collected by officers 2-4 times a week. Only $17 \%$ of the total number of respondents stated that their garbage was collected daily by officers.

\subsection{Knowledge towards the solid waste management system}

This research measures respondent's knowledge, attitude, and practice towards the application of the $3 R$ Principle in the household solid waste management. There are eight indicators used to measure the knowledge towards the application of 3R Principles, which are knowledge towards (1) type of household waste; (2) effect of the household waste to the household member; (3) effect of the household waste to its surrounding environment; (4) how to manage household solid waste; (5) the 3R principle; (6) benefit 
of applying the $3 \mathrm{R}$ principle in the household waste management; (7) citizen obligation in the household waste management; and (8) the household waste management system at the regency level. The survey result is presented in the Table 1 below.

Table 1. Survey Result

\begin{tabular}{|c|c|c|c|c|c|}
\hline No & Variables & Sufficient & Good & $\begin{array}{l}\text { Very } \\
\text { Good }\end{array}$ & Totals \\
\hline \multicolumn{6}{|c|}{ A. Knowledge } \\
\hline \multirow{2}{*}{1} & \multirow{2}{*}{$\begin{array}{l}\text { Type of } \\
\text { Household } \\
\text { Waste }\end{array}$} & 7 & 226 & 67 & \multirow{2}{*}{300} \\
\hline & & $2,3 \%$ & $75,3 \%$ & $22,3 \%$ & \\
\hline \multirow[b]{2}{*}{2} & \multirow{2}{*}{$\begin{array}{l}\text { Effect of the } \\
\text { Household } \\
\text { Waste to the } \\
\text { household }\end{array}$} & 1 & 218 & 81 & \multirow{2}{*}{300} \\
\hline & & $0,3 \%$ & $72,7 \%$ & $27,0 \%$ & \\
\hline \multirow{2}{*}{3} & \multirow{2}{*}{$\begin{array}{l}\text { Effect of the } \\
\text { Household } \\
\text { Waste to the } \\
\text { environment }\end{array}$} & 3 & 234 & 63 & \multirow{2}{*}{300} \\
\hline & & $1,0 \%$ & $78,0 \%$ & $21,0 \%$ & \\
\hline \multirow{2}{*}{4} & \multirow{2}{*}{$\begin{array}{l}\text { Household } \\
\text { Solid Waste } \\
\text { Management }\end{array}$} & 7 & 248 & 45 & \multirow{2}{*}{300} \\
\hline & & $2,3 \%$ & $82,7 \%$ & $15,0 \%$ & \\
\hline \multirow{2}{*}{5} & \multirow{2}{*}{$\begin{array}{l}\text { The 3R } \\
\text { Principle }\end{array}$} & 4 & 256 & 40 & \multirow{2}{*}{300} \\
\hline & & $1,3 \%$ & $85,3 \%$ & $13,3 \%$ & \\
\hline \multirow{2}{*}{6} & \multirow{2}{*}{$\begin{array}{l}\text { Benefit of } \\
\text { applying the } \\
\text { 3R principle }\end{array}$} & 2 & 262 & 36 & \multirow{2}{*}{300} \\
\hline & & $0,7 \%$ & $87,3 \%$ & $12,0 \%$ & \\
\hline \multirow[b]{2}{*}{7} & \multirow{2}{*}{$\begin{array}{l}\text { Citizen } \\
\text { obligation } \\
\text { towards } \\
\text { household } \\
\text { waste } \\
\text { management }\end{array}$} & 15 & 254 & 31 & \multirow[b]{2}{*}{300} \\
\hline & & $5,0 \%$ & $84,7 \%$ & $10,3 \%$ & \\
\hline \multirow[b]{2}{*}{8} & \multirow{2}{*}{$\begin{array}{l}\text { Regency } \\
\text { Household } \\
\text { Waste } \\
\text { Management } \\
\text { System }\end{array}$} & 6 & 239 & 55 & \multirow[b]{2}{*}{300} \\
\hline & & $2,0 \%$ & $79,7 \%$ & $18,3 \%$ & \\
\hline \multicolumn{6}{|c|}{ B. Attitude } \\
\hline \multirow[b]{2}{*}{1} & \multirow{2}{*}{$\begin{array}{l}\text { Attitude } \\
\text { toward the } \\
\text { application of } \\
\text { the 3R } \\
\text { Principle }\end{array}$} & 27 & 259 & 14 & \multirow[b]{2}{*}{300} \\
\hline & & $9 \%$ & $86 \%$ & $5 \%$ & \\
\hline \multicolumn{6}{|c|}{ C. Practice } \\
\hline \multirow{2}{*}{1} & \multirow{2}{*}{$\begin{array}{l}\text { Practice of the } \\
\text { 3R Principle }\end{array}$} & 93 & 194 & 13 & \multirow{2}{*}{300} \\
\hline & & $31 \%$ & $65 \%$ & $4 \%$ & \\
\hline
\end{tabular}

The survey result shows that most of respondents have a fairly good knowledge regarding the household waste management. In every indicators for the knowledge variable, around $73 \%-85 \%$ of the respondent's answers show that they have good knowledge regarding the household waste management while around 10\%-27\% respondents have very good knowledge regarding the household waste management. Among indicators used to measure the Knowledge towards household waste management, the indicators regarding the effect of the household waste to their family and their surrounding environment, and also regarding the benefit of applying the $3 \mathrm{R}$ principle in the household waste management system are two indicators with the highest proportion of respondents with good and very good knowledge.

Regarding the impact of the household waste management, most of the respondents, namely $27 \%$ of the total number of respondents, have a very good level of understanding regarding the impact of waste management on their own family. The rest, $72,7 \%$ respectively are in the "Good" category and 0,3\% are in the sufficient category. Respondents are also aware of the household waste management impact to their neighborhood. There are $78 \%$ of the respondents have good knowledge regarding the household waste management impact to their neighborbood, while $21 \%$ have very good knowledge and only $1 \%$ have sufficient level of knowledge.

The respondents also have good knowledge regarding the type of household waste, the household solid waste management, the $3 R$ Principle, and also the household waste management system at the regency level. Respondents in general have a very good understanding of the different types of waste between organic, inorganic, and specific household waste. Respondents also have a very good understanding of the types of waste that are divided into easily biodegradable waste, toxic materials and hazardous waste, and waste that can be recycled. From the results of data collection using a questionnaire as much as $22,3 \%$ of the total respondents has very good knowledge of the type of waste, $75,3 \%$ are in the "Good" category, and only 2,3\% are in the "Sufficient" category with no respondents are in the lacking and very lacking category regarding his knowledge of the types of waste.

Similar with other aspects, most of respondents also have good knowledge regarding $3 \mathrm{R}$ principle itself and also acknowledge the benefit of applying $3 R$ Principle in their household waste management. There are in total $98,7 \%$ respondents have good and very good knowledge regarding the application of the $3 \mathrm{R}$ Principle. Most of respondents also acknowledge the benefit from the application of 3R Principle. The survey result shows that actually the respondents have good knowledge regarding the household waste, its effect, and also regarding the application of the $3 R$ Principle. 
The aspect which has a larger portion of respondents with sufficient level of knowledge is regarding the obligation of the citizen in the household waste management. As it is stipulated in the Regency Regulation (Perda Kabupaten Sleman) number 4/2015, the citizen has the obligation to actively participate in the effort to reduce the amount of the household waste. Despite of the lower level of knowledge regarding the citizen obligation in the household waste management, most of the respondents aware of the household management system at the regency level. It is represented by the proportion of the respondents who falls in the category of having good and very good knowledge. There are $79,7 \%$ respondents have good knowledge and $18,3 \%$ respondents have very good knowledge regarding the household management system at the regency level.

\subsection{Attitude and Practice towards the municipal household waste management}

In measuring the attitude variable, it can be seen that most of the respondents have a generally good attitude towards waste management using the $3 \mathrm{R}$ principle. As many as $5 \%$ of the total respondents have a very good attitude and $86 \%$ of respondents have a good attitude towards household waste management using the $3 \mathrm{R}$ principle. These results indicate that basically the community is willing to reduce, sort and recycle their household waste.

In measuring the practice of household waste management with the $3 \mathrm{R}$ principle, it can be seen that only $4 \%$ of the total number of respondents have practiced very good solid waste management based on the $3 \mathrm{R}$ principle. While $65 \%$ of the total number of respondents has a good level of practice and $31 \%$ is sufficient. This shows that waste management based on the $3 \mathrm{R}$ principle is still not well implemented in the study area.

\subsection{Discussion}

Based on the measurement results of the community's knowledge, attitude, and practice towards waste management with the $3 \mathrm{R}$ Principle, it can be seen that in general the community has a good level of knowledge regarding waste management with the $3 R$ principle. The weakest points in the knowledge aspect are the points on the citizen obligation to participate in the household waste management system.

In terms of attitude, basically the people in the research location have a good attitude regarding the application of the $3 R$ principle in household waste management. Most of the respondents stated their approval of the application of the $3 \mathrm{R}$ principle in household waste management. This shows that basically there is a strong commitment in the community to participate in efforts to reduce waste in the Sleman Regency area.

However, this knowledge and good attitude have not been accompanied by solid waste management practices using the $3 \mathrm{R}$ principle. This shows that there is a gap between what the community understands and what the community wants with the implementation of the $3 \mathrm{R}$ principle in household waste management in the study area.

Regarding efforts to increase public understanding of household waste management based on the 3R principle, the government can intensify socialization, especially through social media which is considered quite effective as a medium of communication for government policies. The Sleman Regency government can provide socialization related to the household waste management system in Sleman Regency as well as good household waste processing techniques in Sleman Regency.

The possible explanation why the high level of knowledge and attitude towards the application of 3R principle is not followed by the high level of practice is that the insufficiency in the infrastructure to support the application of 3R Principle. Based on the field observation, it can be seen that the waste collection itself does not separate household waste based on its type. The household waste separation is done in the $3 \mathrm{R}$ Temporary Waste Disposal Site (TPS 3R), which are only available in a few sub-districts.

In order to encourage the application of $3 R$ Principle in the household waste management, there are several efforts that have to be put by the municipal government. First of all, the separation of the household waste based on its type must be encouraged starting from the household level. It should be followed by the improvement in the household waste collection system itself, which also needs to accommodate the household waste separation. Secondly, since the awareness of the society to actively participate in the household waste management system is still low, it is important to encourage citizen participation in the household waste management system. The role of nongovernmental organizations in managing household waste at the dukuh and neighborhood levels needs to be strengthened. In this regard, the Sleman Regency government has taken a step further by providing space for community involvement in waste management. The last but not least, it is necessary to design facilities 
and infrastructure, such as $3 \mathrm{R}$ trash bins, as well as a garbage collection and collection system that accommodates the application of the $3 \mathrm{R}$ principles, to encourage people to apply the $3 \mathrm{R}$ principles in their household waste management.

\section{CONCLUSIONS}

The results showed that the general public has a good knowledge and attitude regarding household waste management using the $3 \mathrm{R}$ principle. However, the community's knowledge needs to be improved, especially regarding good household waste management methods as well as the general waste management system in Sleman Regency. However, this knowledge and good attitude have not been matched by good practice in applying the $3 \mathrm{R}$ principle in household waste management.

The lack of optimal community practice in implementing the $3 \mathrm{R}$ principle can be caused by several factors, namely (1) Lack of public awareness regarding the citizen active participation in the household waste management system and (2) the problem of household waste collection method that has not accommodated the application of 3R Principle.

Similar research can be replicated elsewhere, given the very limited scope of this research area. The replication of this research in other regional units, especially in the Sleman Regency, is expected to provide a comprehensive picture for formulating strategies and policies in a more sustainable household waste management in Sleman Regency.Replication of this research can be done by utilizing an instrument in the form of a questionnaire that has been used in this study. The results of the reliability test using the Cronbach-Alpha method show that the questionnaire used is a reliable instrument to measure people's knowledge, attitude, and practice in waste management using the $3 \mathrm{R}$ principle.

\section{ACKNOWLEDGMENT}

Acknowledgement is given to Institut Teknologi Nasional Yogyakarta that has provided funding for this research.

\section{REFERENCES}

[1] UN Habitat, "World Cities Report 2016. Urbanization and Development: Emerging Futures," 2016.

[2] UN Habitat, "Urbanization and Development. Emerging Future," 2016.
[3] A. Almasi et al., "Assessing the knowledge, attitude and practice of the kermanshahi women towards reducing, recycling and reusing of municipal solid waste," Resour. Conserv. Recycl., vol. 141, no. October 2018, pp. 329-338, 2019.

[4] E. P. Barloa, L. P. Lapie, C. Paul, and P. De Cruz, "Knowledge , Attitudes, and Practices on Solid Waste Management among Undergraduate Students in a Philippine State University," Enviornment Earth Sci., vol. 6, no. 6, pp. 146153, 2016.

[5] Z. Chu, W. Wang, B. Wang, and J. Zhuang, "Research on factors influencing municipal household solid waste separate collection: Bayesian belief networks," Sustain., vol. 8, no. 2, 2016.

[6] M. Banga, "Household Knowledge , Attitudes and Practices in Solid Waste Segregation and Recycling: The Case of Urban Kampala Recycling: The Case of Urban Kampala," Zambia Soc. Sci. J., vol. 2, no. 1, pp. 27-39, 2013.

[7] P. Laor, Y. Suma, V. Keawdounglek, A. Hongtong, T. Apidechkul, and N. Pasukphun, "Knowledge, attitude and practice of municipal solid waste management among highland residents in Northern Thailand," J. Heal. Res., vol. 32, no. 2, pp. 123-131, 2018.

[8] S. B. Mukherji, M. Sekiyama, T. Mino, and B. Chaturvedi, "Resident knowledge and willingness to engage in waste management in Delhi, India," Sustain., vol. 8, no. 10, pp. 1-14, 2016.

[9] C. Kontgis, A. Schneider, J. Fox, S. Saksena, J. H. Spencer, and M. Castrence, "Monitoring periurbanization in the greater Ho Chi Minh City metropolitan area," Appl. Geogr., vol. 53, no. October 2017, pp. 377-388, 2014.

[10] B. J. Shaw, J. van Vliet, and P. H. Verburg, "The peri-urbanization of Europe: A systematic review of a multifaceted process," Landsc. Urban Plan., vol. 196, no. April 2019, 2020.

[11] Sumintrasih and A. Adrianto, Dinamika kampung kota. Yogyakarta: Departemen Pendidikan dan Kebudayaan, Balai Pelestarian Nilai Budaya, 2014.

[12] Departemen Permukiman dan Prasarana Wilayah, "Buku profil penataan ruang," 2003. 
[13] T. Eko and S. Rahayu, "Perubahan Penggunaan Lahan dan Kesesuaiannya terhadap RDTR di Wilayah Peri-Urban Studi Kasus: Kecamatan Mlati," vol. 8, no. 4, pp. 330-340, 2012.

[14] A. Warsono, S. Soetomo, and H. Wahyono, "Perkembangan Permukiman Pinggiran Kota Pada Koridor Jalan Kaliurang Kecamatan Ngaglik Kabupaten Sleman," J. Tata Kota dan Drh., vol. 1, no. 1, pp. 19-23, 2009.

[15] A. N. Faizah and M. Hendarto, "Analisis difusi keruangan di sekitar kawasan perkotaan yogyakarta," Diponegoro J. Econ., vol. 2, no. 3, pp. 1-9, 2013.

[16] A. A. Babaei, N. Alavi, G. Goudarzi, P. Teymouri, K. Ahmadi, and M. Rafiee, "Household recycling knowledge, attitudes and practices towards solid waste management," Resour. Conserv. Recycl., vol. 102, pp. 94-100, 2015.
[17] W. S. Pangaribowo, "Yogyakarta Darurat Sampah akibat TPST Piyungan Ditutup, Depodepo Sampah Penuh hingga Pilih Tutup," kompas.com, 2020. [Online]. Available: https://regional.kompas.com/read/2020/12/22/05 300021/yogyakarta-darurat-sampah-akibat-tpstpiyungan-ditutup-depo-depo-sampah?page=all.

[18] P. Edi, “TPST Piyungan Ditutup, Sampah di Yogyakarta Membludak," merdeka.com, 2020. [Online].Available:

https://www.merdeka.com/peristiwa/tpstpiyungan-ditutup-sampah-di-yogyakartamembludak.html.

[19] S. Subekti, "Pengelolaan Sampah Rumah Tangga 3R Berbasis Masyarakat," in Prosiding Seminar Nasional Sains dan Teknologi 2010, 2010, pp. 24-30.

[20] S. Lee and H. S. Paik, "Korean household waste management and recycling behavior," Build. Environ., vol. 46, no. 5, pp. 1159-1166, 2011. 